\title{
HOTS in Quadratic Equations: Teaching Style Preferences and Challenges Faced by Malaysian Teachers
}

\author{
Richeal Phil Thien Kim How ${ }^{1 *}$, Hutkemri Zulnaidi ${ }^{1}$, Suzieleez Syrene Abdul Rahim ${ }^{1}$ \\ ${ }^{1}$ University of Malaya, Kuala Lumpur, MALAYSIA \\ * Corresponding author: ritzphil1987@gmail.com
}

Received: 11 Jun. $2021 \bullet$ Accepted: 17 Oct. 2021

Citation: Kim How, R. P. T., Zulnaidi, H., \& Abdul Rahim, S. S. (2022). HOTS in Quadratic Equations: Teaching Style Preferences and Challenges Faced by Malaysian Teachers. European Journal of Science and Mathematics Education, 10(1), 15-33. https://doi.org/10.30935/scimath/11382

\begin{abstract}
:
The purpose of this study is to identify the teaching styles and problems faced by teachers as they attempt to cultivate higher-order thinking skills (HOTS) in the topic of quadratic equations. This study used a qualitative approach via structured interview involving four participants who are experienced mathematics teachers from three districts in Malaysia. Data obtained were analysed using the ATLAS.ti 8 software by dividing the transcripts into small codes based on thematic analysis. The results revealed that Malaysian teachers have limited and general understanding about higherorder thinking skills for the topic of quadratic equations. The interview results also found that existing teaching styles mainly involve teacher-centred strategies that emphasise on the memorisation of procedures or facts as well as steps to solve quadratic equation problems. Among the challenges faced by teachers were stated as students' acceptance, lack of teaching aids, teaching strategies in the classroom, and students' thinking skills. The findings of this study can help to refine and improve several shortcomings and weak students can be exposed to the learning of higher-order thinking skills in quadratic equations via real-life projects. It is proposed for future research to focus on integrating digital literacy, such as Desmos Graphing Calculator, in cultivating higher-order thinking skills for quadratic equations.
\end{abstract}

Keywords: challenges, higher-order thinking skills (HOTS), quadratic equations, teaching style

\section{INTRODUCTION}

Mathematical knowledge often refers to the numerical system and basic operations particularly pertaining to problem-solving (Waller \& Flood, 2016). It comprises symbols and spaces that are divided into a number of components including arithmetic, calculus, geometry, and algebra (Jubri et al., 2019). In this regard, quadratic equations is one of the clusters in algebra that is compulsory to be learned by all secondary school students (Cahyani \& Rahaju, 2019), and subsequently poses a direct impact to the new transformation of the national curriculum. At the secondary school level, quadratic equations is a compulsory topic in the learning of mathematics and additional mathematics. In the context of form four secondary school core mathematics, students will be introduced to Chapter 1: Quadratic Functions and Equations in One Variable, which is the earliest chapter in the form four syllabus. This topic is introduced at the beginning of the lesson as it is the main mathematical foundation that students should master before they begin to learn other topics. In fact, students have been exposed to basic quadratic formula since the early stage of schooling, that is as early as form two (Curriculum Development Division [CDD], 2018). Pertinent focus on the concept of quadratic equations to fulfil the needs of a multi-level curriculum, thus illustrates its importance to be learned and mastered. Despite its importance, the concept of quadratic equations is also the most challenging algebraic domain to be mastered among other contents in a mathematics syllabus (Güner, 2017). 
Quadratic equations are among the major fixtures in the mathematics curriculum. Students are required to solve quadratic equation problems in almost every national standardised test. The inclusion of quadratic equations as part of the mathematics syllabus for secondary schools worldwide is because it is a basic mathematical skill that has been expanding alongside the advancement of algebra (Didis \& Erbas, 2015). Numerous strategies to solve quadratic equation problems have been acknowledged by mathematicians since immemorial time and it continues to evolve and be used in the present day, with continuous studies being conducted in the field of algebra. This begins from the strategy through arithmetic and numerical representations, algebra and symbols, and utilising visual and geometrical techniques (Katz \& Barton, 2007). Moreover, Sağlam and Alacacı (2012) have posited that from the contemporary perspective, quadratic equations are deemed important in a school curriculum because it helps to establish a connection of knowledge between mathematical topics such as linear equations, functions, and polynomial derivatives. Besides linear equations, quadratic equations are another important component in making strong representations to solve problems of various disciplines, including physics, engineering, and structural design. This is prompted by its suitability to illustrate ideas through models that are realistic or similar to real-life situations (Didis \& Erbas, 2015).

\section{PROBLEM STATEMENT}

\section{Higher-order Thinking Skills in Mathematics}

Higher-order thinking skills (HOTS) in mathematics has received serious attention by the Ministry of Education (MoE) Malaysia, as evident by its explicit inclusion into the national education curriculum (Hassan et al., 2017). Students' ability to think using higher-order thinking skills in mathematics serves as an important employability factor to face the growing challenges in the employment industry (Gani, 2018). This subsequently justifies higher-order thinking skills as a basic professional skill with a prominent demand in the industry that determines a graduate's qualification to secure a job (Hasan \& Pardjono, 2019). However, Misrom et al. (2020) have reported that the level of higher-order thinking skills among students in Malaysia is still low and yet to be at par with the standard set by the MoE. One of the challenges faced by students is solving mathematical problems in the form of long sentences (Suanto et al., 2019). Mathematical questions that take the structure of long texts with multiple information often confuse students as they attempt to digest its main objective. This is consistent with Hasan (2019), who has explored students' mastery of higher-order thinking skills in solving mathematical questions based on Programme for International Student Assessment (PISA) standard questions. The finding showed that students faced difficulty to devise a complete solution and they were unable to make appropriate connection between the mathematical formula with the given higherorder thinking skills questions. In addition, an investigation by Hadi et al. (2018) on students' difficulty to solve higher-order thinking skills items pertaining to the topics of probability, differences, and functions, reported a high percentage of students who demonstrated no attempts to answer the higherorder thinking skills questions, with an average percentage of $42.47 \%$.

According to Zulkifli et al. (2018), there are three main factors that can influence students' capability to answer higher-order thinking skills questions, namely their attitude, learning materials, and teachers' teaching approach. The statement, hence, suggests that the instillation of higher-order thinking skills is closely associated with the teachers' teaching strategy (Marzni et al., 2018). However, a study by IrmaAin and Zolkepeli (2017) have found that mathematics teachers in Malaysia are less skilled in applying strategies for the usage and learning of higher-order thinking skills in teaching and learning. The finding is supported by Friyatmi (2020), who has reported that most teachers are incapable of formulating higher-order thinking skills related questions and items. The difficulties faced by the teachers in constructing higher-order questions show that the challenge of cultivating higher-order thinking skills within the teaching of mathematics not only arises from the aspect of pedagogical skills, but also insufficient existing knowledge among the teachers. It is important for these issues to be acknowledged and addressed to avoid its impact on the cultivation of higher-order thinking skills in mathematics education. 


\section{Quadratic Equations}

Although the topic of quadratic equations is perceived as easy and only involves basic skills, many human's daily life revolves around the adaptation of quadratic equations concepts such as its applications in sports and architecture (Yeow et al., 2019). There are a number of issues and challenges faced by students in learning quadratic equations including their weak mastery of the algebraic procedural knowledge such as quadratic equations factoring methods along with their incapability to interpret the meaning and information within quadratic equations (Didis \& Erbas, 2015). Kotsopoulos (2007) has advocated the statement by stating that students' difficulty to recall the process of multiplication or expansion of algebraic expressions directly affects their capability to use factoring method in solving quadratic problems. Moreover, factoring method also requires students to quickly identify the roots to quadratic equations, which prompts them to commit minor mistakes when factoring quadratic equations such as sign errors, missing values, and do not equate the factoring steps with the value of ' 0 ' (Rosli \& Rasdi, 2015).

Tall et al. (2014) have propounded that students' lack of procedural knowledge on linear equations and their understanding that is based on "planned procedures" often influence their capability to solve quadratic equations. Although the majority of students are capable to use the method meaningfully, a number of them use it without having a good grasp on its reason. Students also practise rule-based problem solving like memorising steps and formula to solve quadratic equation problems, subsequently limiting their understanding that "unknown" is a key feature in quadratic equations (Didis \& Erbas, 2015). Although the method of memorising procedures and operational symbols does produce accurate solutions, it confines students to only one solution technique.

The main key in learning this topic is to determine the root or $x$-intercept value of a quadratic equation. There are a number of methods introduced in the content of mathematics syllabus worldwide, including the trial-and-error method, using the square roots, factoring method, completing the square, geometrygraphic method, and by using quadratic formula. Despite the availability of these methods, past studies reported that both teachers and students prefer the factoring method involving the operationalisation of symbols than other solving methods ( $\mathrm{O}^{\prime}$ Connor \& Norton, 2016). This is alarming, as most everyday life problems involving the quadratic equations concept cannot be solved using the factoring method; nevertheless, even the majority of textbooks and reference books available only contain quadratic equations that can be factorised easily (McCarthy, 2020). For example, the application of quadratic equations in designing geometrical structure models is more precise via the completion of the square method as compared to other methods (Norton, 2015). This has suggested that the teachers' tendency to avoid from teaching alternative methods such as completing the square and quadratic formula due to the high number of errors committed by the students (Zakaria et al., 2010).

Various problems and obstacles exist in the teaching and learning of the quadratic equations topic at the school level. According to Sari and Jailani (2019), among the issues in the teaching and learning of the quadratic equations from the teachers' context were: teachers are too fast in delivering quadratic equations teaching materials, and teachers' present a dull and boring delivery that causes students to lose interest with the topic. The study also reported that most students view quadratic equations as a difficult topic to be learnt and they are unable to find learning materials on the topic. This calls for serious attention to the issue, especially in teaching the quadratic equations topic. In addition, the students' difficulty to further their studies in the science stream at the university level is closely related to their failure in mastering the basic knowledge of quadratic equations, which is a key prerequisite for accessing higher mathematical knowledge. Although this topic is important for students to master, there is still a lack of studies that emphasise appropriate pedagogical practice in the topic of quadratic equations (O'Connor \& Norton, 2016). Aligned with this view, Teh (2015) has highlighted the existence of various studies related to algebra in education, however, investigation on quadratic equations teaching practices is still limited. Therefore, this study attempts to provide a clearer picture on the teachers' understanding, existing teaching styles, and the problems faced by local teachers in integrating 
students higher-order thinking skills for the topic of quadratic equations. The following research objectives and questions thus guide the analysis:

\section{Research Objective}

1. To determine the level of teachers' understanding in defining higher-order thinking skills for the topic of quadratic equations.

2. To identify the teaching styles and problems faced by teachers in implementing the teaching and learning of higher-order thinking skills in the topic of quadratic equations.

\section{Research Question}

1. What is the teachers' level of understanding in defining higher-order thinking skills for the topic of quadratic equations?

2. Throughout their teaching experience, what are the teaching styles that the teachers have implemented to promote higher-order thinking skills for the topic of quadratic equations?

3. What are the problems faced by the teachers in implementing the teaching and learning of higherorder thinking skills in the topic of quadratic equations?

\section{METHODOLOGY}

This study has employed a qualitative approach via a series of structured face-to-face interviews that were conducted at the participants' schools. The advantage of using the structured interview instrument is that all participants will receive a similar set of questions, thus allowing for their answers to be compared, arranged, and analysed more meaningfully (Rashidi et al., 2014). In a structured interview, the researcher will play the role of a moderator who prepares the questions that will be asked to the participants (Lebar, 2018). The Structured Interview Protocol used in this study was adapted from Zulnaidi (2013), that was previously aimed to obtain information from mathematics teachers about the teaching and learning of calculus as well as the problems encountered. The protocol has been refined and modified to suit the objective of this study which is to obtain verbal data from mathematics teachers about the teaching approaches and problems faced by them in implementing the teaching and learning of higher-order thinking skills in quadratic equations. The interview also contained questions about the teachers' existing knowledge on the difference between higher-order thinking skills questions and low order thinking skills for the topic of quadratic equations.

\section{Research Sample}

The selection of participants for the interview was done through the snowball sampling technique. It refers to the technique of choosing the research subjects based on the reference of individuals who know the prospective participants (Aripin et al., 2014). In this study, four mathematics teachers from three districts in Malaysia were recruited as the participants, following the suggestions from their respective schools. The researcher also selected the research sample based on the recommendations by Spencer and Spencer (1993), who have posited that identifying the exact informants for research is sufficient by referring to the employer, or the nomination submitted by the employer. The use of the snowball sampling technique is important as the contact persons, namely the Principals, Senior Assistants of Curriculum, and Heads of Mathematics Department, could suggest the teachers who would be able to provide in-depth and rich information regarding the topic under investigation (Nasir \& Hamid, 2019). The selection was done following their vast experience such as serving as the Head of Mathematics Department and possessing more than seven years of teaching experience. Such conditions are in line with Johari et al. (2009), who have propounded that the teachers with more than seven years of teaching experience are deemed as highly experienced and confident in teaching strategies, students' engagement, and classroom management. These teachers also have a degree specialisation in Mathematics Education and are actively involved in professional education development. At this stage, 
adding more participants was unnecessary due to data saturation, except for specific topics or issues. Creswell (2012) has posited that the ideal number of qualitative participants is between 3 to 10 participants, depending on the depth of the study. This justifies the selection of the four teachers in this phase in relation to the objective of the study. The researcher was allowed three weeks to interview the four mathematics teachers from the three districts. The participants were labelled as G1, G2, G3, and G4. The code G refers to the abbreviation of Guru (Teacher).

\section{Pilot Study}

The validity and reliability used by the researcher in this phase comprised several measures proposed by Bogdan and Biklen (2007), namely the validation of interview protocol by field experts, pilot study, data triangulation, and participants' validation on the interview data. Although pilot study is commonly associated with a quantitative study design to assess the validity and reliability of a research instrument, its importance has been expanded to qualitative research design as well (Majid et al., 2017). Besides providing initial training as well as familiarising researchers with the protocols and procedures of conducting interviews, pilot study can also test the suitability of the protocols (Yin, 2014). A pilot study of the Structured Interview Protocol for Mathematics Teachers was conducted at a national secondary school in the Tawau district. A teacher deemed suitable to represent the research subjects was selected. The teacher was an experienced teacher who holds the position of the Head of Science and Mathematics Department. An interview session was conducted and upon completion, the notes made by the researcher and the participant were used to make further improvements. Findings from the pilot study were used as a reference to identify the issues and aspects to be considered during the actual interview. Prior to the pilot study, the completed interview protocol was reviewed by three experts, who comprised of two public university lecturers with expertise in mathematics and higher-order thinking skills education as well as a language expert from the Language Department at the Institute of Teacher Education Malaysia, to see the coherence between the research objectives and language appropriateness.

\section{Data Analysis and Triangulation}

All data collected from the structured interviews were analysed using the ATLAS.ti 8 software. Thematic analysis was conducted using the ATLAS.ti 8 software (see Figure 1), to analyse the interview transcripts of the mathematics teachers about the teaching and learning of mathematics, such as the level of knowledge and the teaching styles implemented by them for the topic of quadratic equations among form four students, as well as the problems that they faced in the application of higher-order thinking skills within the topic. Transcripts of the teachers' answers were carefully analysed, divided into small codes, and coded based on themes that were appropriate with the research questions (Braun \& Clarke, 2006). This qualitative analysis was conducted by dividing the teachers' teaching styles and challenges faced by teachers based on appropriate themes.

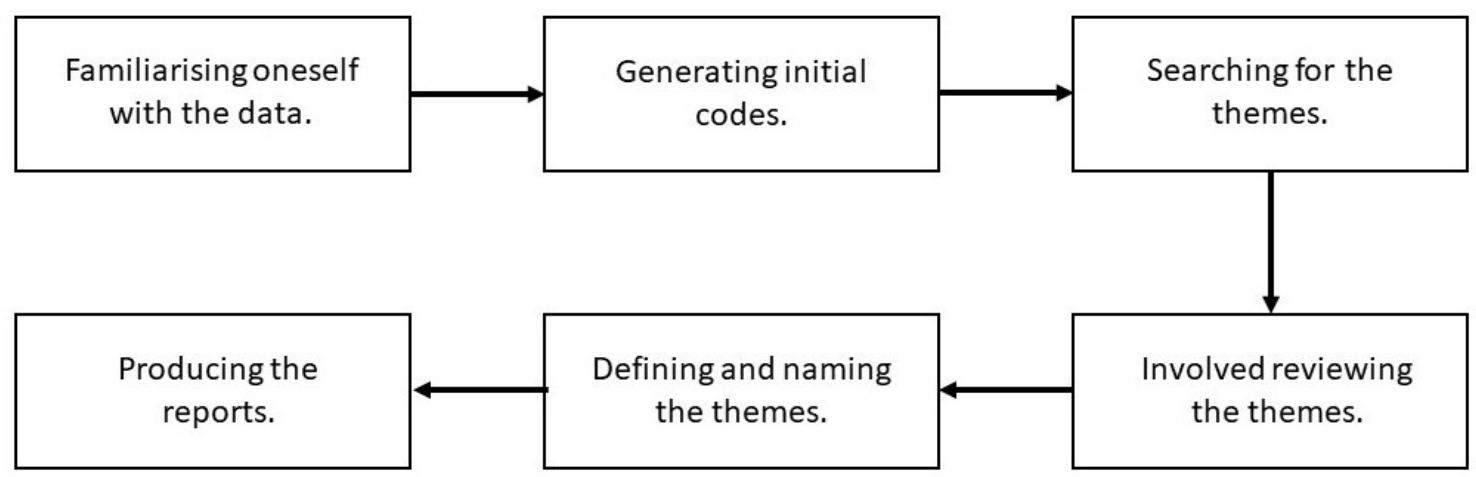

Figure 1. Data analysis procedures 
Triangulation was conducted to address any weaknesses and biases in the qualitative data analysis. The type of triangulation used in this study was the within-method triangulation as suggested by Talib (2019). The researcher used the same questions in the interview protocol but implemented at two different times to improve the validity of the answers (data) given by the participants. In addition, Bogdan and Biklen (2007) have suggested that the validation of qualitative interview data can be done by having the written interview transcripts reviewed and signed by the participants in order to improve its validity and reliability. The participants were allowed to correct any errors or inaccurate information in the transcripts before signing it, once they were satisfied. This can avoid any errors that could affect the quality of the research. In addition to assigning each participant with an acronym for identification purposes, information such as their full name and place of duty were classified as confidential and carefully stored in a locked storage on Google Drive and labelled as Confidential. This is to ensure that the research was conducted in accordance with the guidelines of the Ethical Considerations and Data Privacy, as well as the research permission authorized by the Education Research Policy Division, Ministry of Education Malaysia.

\section{RESULTS AND DISCUSSION}

A total of three themes have emerged from the analysis of the research questions: namely (i) Teachers' understanding in defining higher-order thinking skills; (ii) Higher-order thinking skills teaching style; and (iii) Problems in the teaching and learning of higher-order thinking skills for the quadratic equations topic.

\section{Theme 1: Teachers' Understanding in Defining Higher-order Thinking Skills for Quadratic Equations}

Teachers' understanding in defining higher-order thinking skills for quadratic equations consists of five main codes: namely (1) Bloom's Taxonomy Level; (2) Non-Specific; (3) Stimulus; (4) Broad Scope of Situation; and (5) Meaningful and Challenging. The emerging themes and codes are summarised using the schematic diagram in Figure 2.

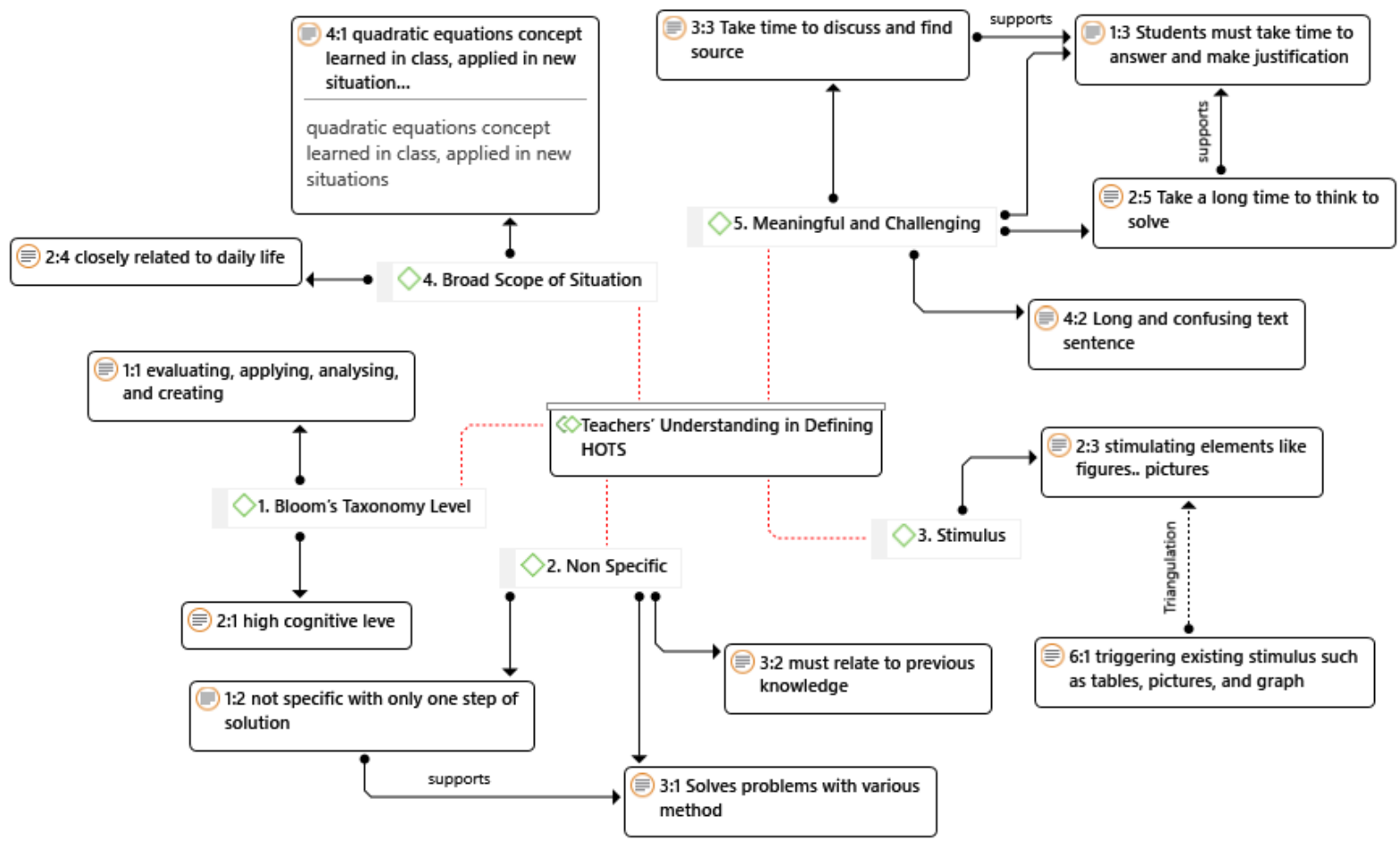

Figure 2. Teachers' understanding in defining HOTS 
It is important for teachers to have a good understanding in defining higher-order thinking skills for the topic of quadratic equations. Confusion over the concept of higher-order thinking skills and relating it to quadratic equations problems will occur if full understanding is not mastered by the teachers. This is to ensure that the teachers would be more confident in generating questions as well as planning various teaching strategies to foster higher-order thinking skills among students.

Analysis of the interview transcripts indicated that the teachers have the basic knowledge on the definition of higher-order thinking skills. From the analysis of the interview transcripts, it was clear that the teachers only possess basic knowledge pertaining to the definition of higher-order thinking skills. For example, the participants G1 and G2 only understood about the position of higher-order thinking skills, which are located at the four highest cognitive levels in Bloom's Taxonomy. However, only one respondent, G1, was able to provide further details about the respective skills, namely evaluating, applying, analyzing, and creating. However, this given understanding is still too general and the description of each level was unclear. In realizing the comprehensive practice of higher-order thinking skills, the teachers' knowledge related to the implementation of each cognitive level of the higher-order thinking skills must be clear and accurate. This includes the criteria and teaching approaches related to the measurement of higher-order thinking skills levels. For example, the higher-order thinking skills' skill of analyzing describes the students' ability to break down conceptual sources of ideas such as the problem of measuring school field parameters into small parts like width, length, and field area, before determining how these parts are related to one another to form a quadratic equation in explaining the overall model.

Furthermore, Teacher 1 (G1) also emphasised that the definition of problems in the form of higher-order thinking skills is asking questions with solutions that are not immediately clear or are not specific with only one step of solution. Teacher 3 (G3) also advocated this statement by stating that higher-order thinking skills' problems should be able to encourage students to apply more than one solution. To quote Teacher 3 (G3):

G3: "HOTS questions.in math for me are more challenging because students can solve problems with various methods. So..have to be creative and critical thinking when answering HOTS questions."

(Int-G3-15/7/2020: 32-35)

Teacher 3 (G3) also added that non-specific higher-order thinking skills' solution methods included the students' ability to integrate one concept with another mathematical topic as well as manipulating the concept to solve the higher-order thinking skills problem.

Apart from the non-specific context of higher-order thinking skills, the teachers also understood the term higher-order thinking skills, by stating that among the criteria for higher-order thinking skills' problems is the inclusion of stimulus in the form of tables, pictures, or graphs. Its function is to provide a picture or clue to the respective higher-order thinking skills problems. As Teacher 2 said:

G2: "Usually it gives stimulating elements like figures.. pictures in HOTS problems usually have a connection with daily life."

(Int-G2-15/7/2020: 36-38)

The statement is further supported by a description about the function of stimulus in higher-order thinking skills' problems obtained from the triangulation interview session with G2:

G2: "...the questions have the element of triggering existing stimulus such as tables, pictures, and graphs. To me, the function of every element in HOTS questions is for students to think and relate with HOTS questions." 
The results also revealed a number of interview excerpts by G2 and G4 that described the Broad Scope of Situation code. In realising the teaching and learning of higher-order thinking skills, these teachers have placed each concept of quadratic equations taught in a different situation, but still within the same operating space and principles.

G2: "...HOTS concepts that are closely related to daily life..students in my class did not know the use of quadratic equations in their daily lives."

(IntT-G2-05/11/2020: 44-46)

The statement by G2, hence, indicated that a higher-order thinking skills-oriented understanding can happen if the students were able to relate the basic principles and concepts within the topic of quadratic equations to the situations that occur around them.

In this study, the researcher also asked the participants to provide examples of higher-order thinking skills questions related to the topic of quadratic equations. All four participants were able to give the situation of the problems clearly but in a limited scope, with several of them were not confident to construct higher-order thinking skills question immediately, rather had to obtain it from the textbook. Such finding is in line with Wilson and Narasuman (2020) who have found that teachers integrated higher-order thinking skills into instruments by referring, adapting, or adopting any instruments available in the books. They did not identify in advance whether the problems referred from the books were in the form of higher-order thinking skills or low order thinking skills (LOTS). The following are some of the examples given by the participants:

G1: The total surface area of the box is $4800 \mathrm{~cm}^{2}$. John's budget to build the frame of a box is 15 Malaysian Ringgit. Determine whether John has sufficient budget to build the frame." (Teacher referred to textbook)

(Int-G1-15/7/2020: 49-51)

G2: "form a quadratic equation using the size and measurement given in the picture of the paddy field. Then, students have to solve the quadratic equation been given...something like that."

(Int-G2-15/7/2020: 41-42)

In conclusion, the findings of this study show that teachers still have limited and incomplete understanding about higher -order thinking skills especially for the topic of quadratic equations. Their knowledge about higher-order thinking skills is also limited to only knowing its position within the four highest levels of Bloom's Taxonomy Model. All four teachers were also unable to provide detailed descriptions about the important cognitive levels of higher-order thinking skills such as applying, analyzing, evaluating, and creating. Teachers' understanding of higher-order thinking skills was also found to be generic, whereby they were only able to understand the concept based on keywords. Furthermore, they also had limited capability to construct higher-order thinking skills questions for the topic of quadratic equations and they had to refer to reference books before being able to give examples of higher-order thinking skills problems. This is because most of them only receive information from in-service training courses and translations from secondary sources such as workbooks, which are indeed inadequate, due to the possibility of information leakages. Following the analysis and discussion on the findings, the researchers have concluded that teachers still do not have full understanding in the implementation of higher-order thinking skills for the topic of quadratic equations. These findings are in line with Mahendran et al. (2021), who have demonstrated that local mathematics teachers find it difficult to formulate appropriate mathematics higher-order thinking skills questions for assessment purposes. 


\section{Theme 2: Hinger-order Thinking Skills Teaching Style for Quadratic Equations}

The styles of teaching higher-order thinking skills for quadratic equations consisted of three main codes: namely (1) Teacher-Centred Strategy; (2) Use of Teaching Aids; and (3) Students-Centred Strategy. These emerging themes and codes are summarised using a schematic diagram as shown in Figure 3.

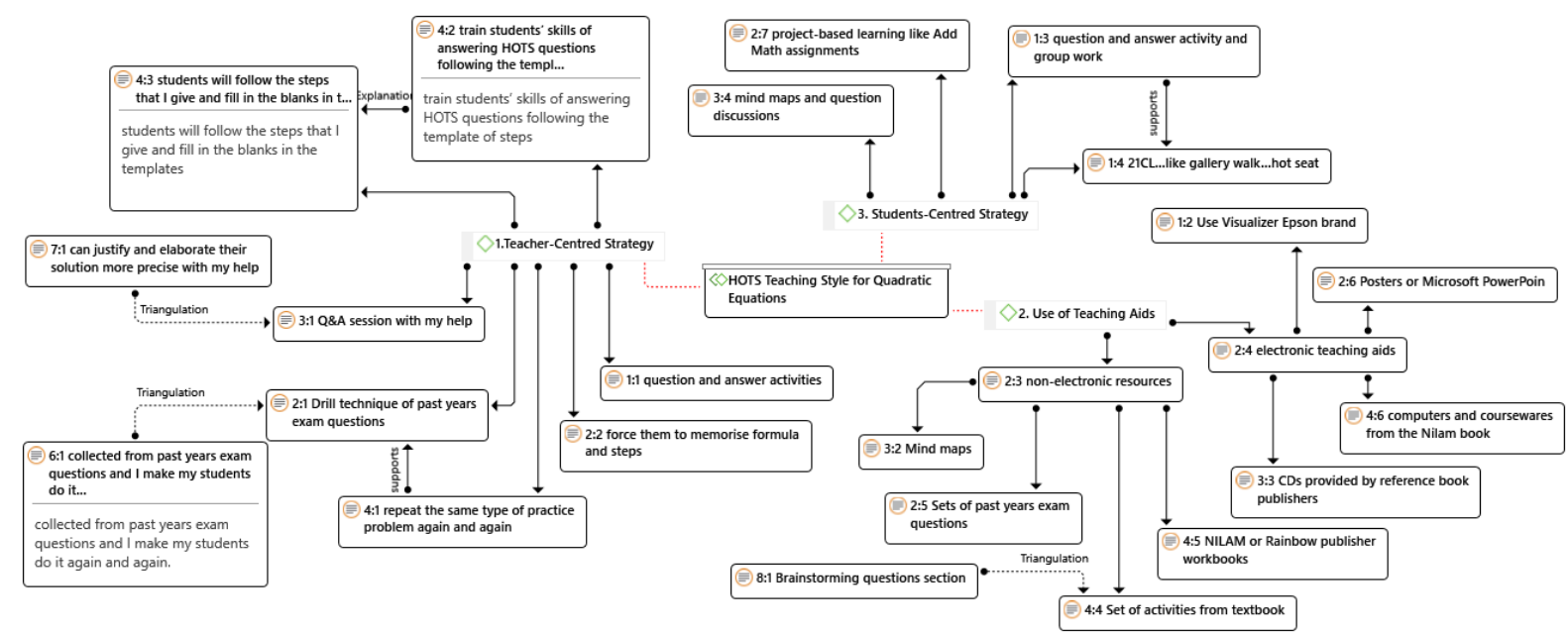

Figure 3. HOTS teaching styles for quadratic equation

It is without a doubt that all four teachers acknowledged of using a teacher-centred or trainer-as-expert teaching style as a strategy to teach higher-order thinking skills. The finding suggests that although this style has always been the target of criticism, drills or drilling technique provided entirely by teachers are seen to be capable of strengthening the higher-order thinking skills for quadratic equations, because students need to master a problem before moving to the next higher-order thinking skills problem. G2 supported this statement because students who repeatedly do higher-order thinking skills exercises tend to have an initial idea about the form of quadratic equation questions that will be included in the public examination. $\mathrm{G} 2$ also added:

\section{G2: "...force them to memorise formula and steps, basic concepts, and graphs... students will remember if we repeat many times until they master all HOTS that they are weak in."}

(Int-G2-15/7/2020: 57-59)

Triangulation of the interview data by G2 also provided further details about the exercises given to the students:

G2: "...HOTS questions on quadratic equations that I collected from past years exam questions, and I make my students do it again and again."

\section{(IntT-G2-05/11/2020: 36-37)}

In addition to the drilling strategy, the study found that the teachers also use demonstration technique as one of the teaching styles of higher-order thinking skills. They will demonstrate how to implement the steps to solve quadratic equation problems in front of the students and they (i.e., the students) will then imitate the given procedures. As said by Teacher 4 (G4):

\footnotetext{
G4: "... show step by step to solve HOTS problems... I will train students' skills of answering HOTS questions following the template of steps and formula that is clear and easy that I have prepared."
}

G4 further added: 
G4: "...students will follow the steps that I give and fill in the blanks in the templates that I have prepared during examination..however, this needs lots of practice."

(Int-G4-22/7/2020: 60-62)

Furthermore, numerous interview excerpts from Teacher 1 (G1) and Teacher 3 (G3), mentioned the question and answer technique. For example, Teacher 3 showed the students of the steps to solve a quadratic equation related to a curved parabolic construction and allowed them to ask questions about what they did not understand, before helping to answer the arising questions. Although there are efforts by the teachers in encouraging students to ask questions, this method still considers teachers as the main source of reference in teaching and learning. The triangulation of interview findings with G3 provided details on the advantages of this strategy:

\section{G3: "...Because students can justify and elaborate their solution more precise with my help."}

(IntT-G3-05/11/2020: 28-29)

All four teachers also acknowledged the need for electronic teaching aids such as technological hardware as well as digital and non-electronic resources like appropriate workbooks to support higherorder thinking skills teaching strategies for quadratic equations. This is because, the use of different types of teaching aids enables teachers to deliver lessons easily and effectively. For example, Teacher 2 (G2) used workbooks to prepare approximately 50 higher-order thinking skills questions for students' training sessions. Meanwhile, G4 and G3 used digital courseware resources such as CDs provided by reference book publishers, however, they faced difficulties to use them because it is costly and cannot be easily accessible. To quote Teacher 4 (G4):

G4: "... I have tried to teach HOTS using computers and coursewares from the workbook but it was too sophisticated to be prepared."

(Int-G4-22/7/2020: 70-71)

Teacher 3 (G3) advocated the statement by stating:

G3: "...even if there is, the cost will be high. The department can't afford it."

(Int-G3-15/7/2020: 168-169)

Additionally, the interview results found that the existing teaching styles also involve the studentscentred strategy. G1 and G3 agreed that higher-order thinking skills in quadratic equations can be fostered through group work, because it encourages students to communicate and collaborate with their peers. This argument was stated by G1 and G3 as follows;

G1: "Sometimes, I do question and answer activity and group work so that students can critically think HOTS answers."

(Int-G1-15/7/2020: 64-65)

G3: "...I also have tried mind maps and question discussions in class but it took too much time and the class was too noisy."

(Int-G3-15/7/2020: 55-56)

As stated by Teacher 3, teachers need to wisely control the class during group discussion activities to avoid it from becoming noisy and disrupting the teaching and learning process. G1 also acknowledged the implementation of the 21st Century Learning (21CL) Activity, as one of the approaches to teach 
higher-order thinking skills in quadratic equations. 21CL activities conducted in groups or in pairs are intended to promote mathematical communication and exchange of ideas among students.

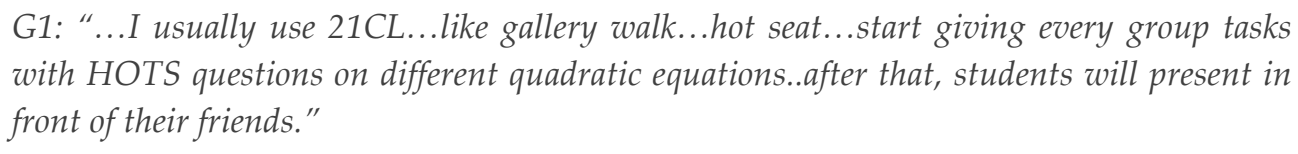

(Int-G1-15/7/2020: 58-60)

However, Teacher 1 believed that despite its advantages, students might feel bored with 21CL activities.

Furthermore, project work was also conducted by the teachers as one of the students' self-learning in strengthening the higher-order thinking skills for the topic of quadratic equations. This strategy emphasises on field research in the form of projects as a way for students to obtain solutions to a problem. Teacher 2 (G2) explained:

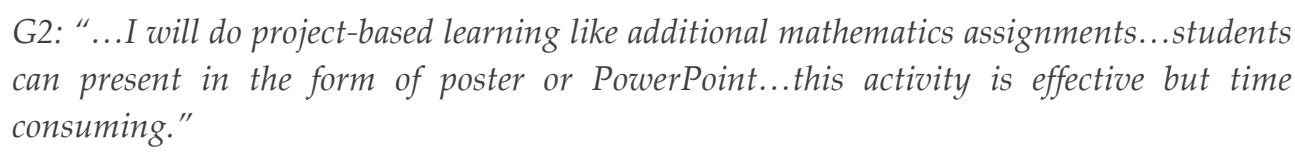

(Int-G2-15/7/2020: 67-69)

G2 further added that the activity usually takes longer time to be completed.

\section{Theme 3: Issues in the Teaching and Learning of Higher-order Thinking Skills in the Quadratic Equations Topic}

Higher-order thinking skills have long been introduced in the mathematics curriculum, but the findings of this study revealed that there are still various problems faced by the teachers and students, particularly in the teaching and learning of higher-order thinking skills in the topic of quadratic equations. Different perspectives were expressed by all four teachers regarding these challenges. There were four main codes that emerged under this theme: namely (1) teaching aids issues; (2) students' attitude; (3) concepts and thinking skills; and (4) teachers' teaching and learning strategies. The emerging themes and codes are summarised using the schematic diagram in Figure 4. 


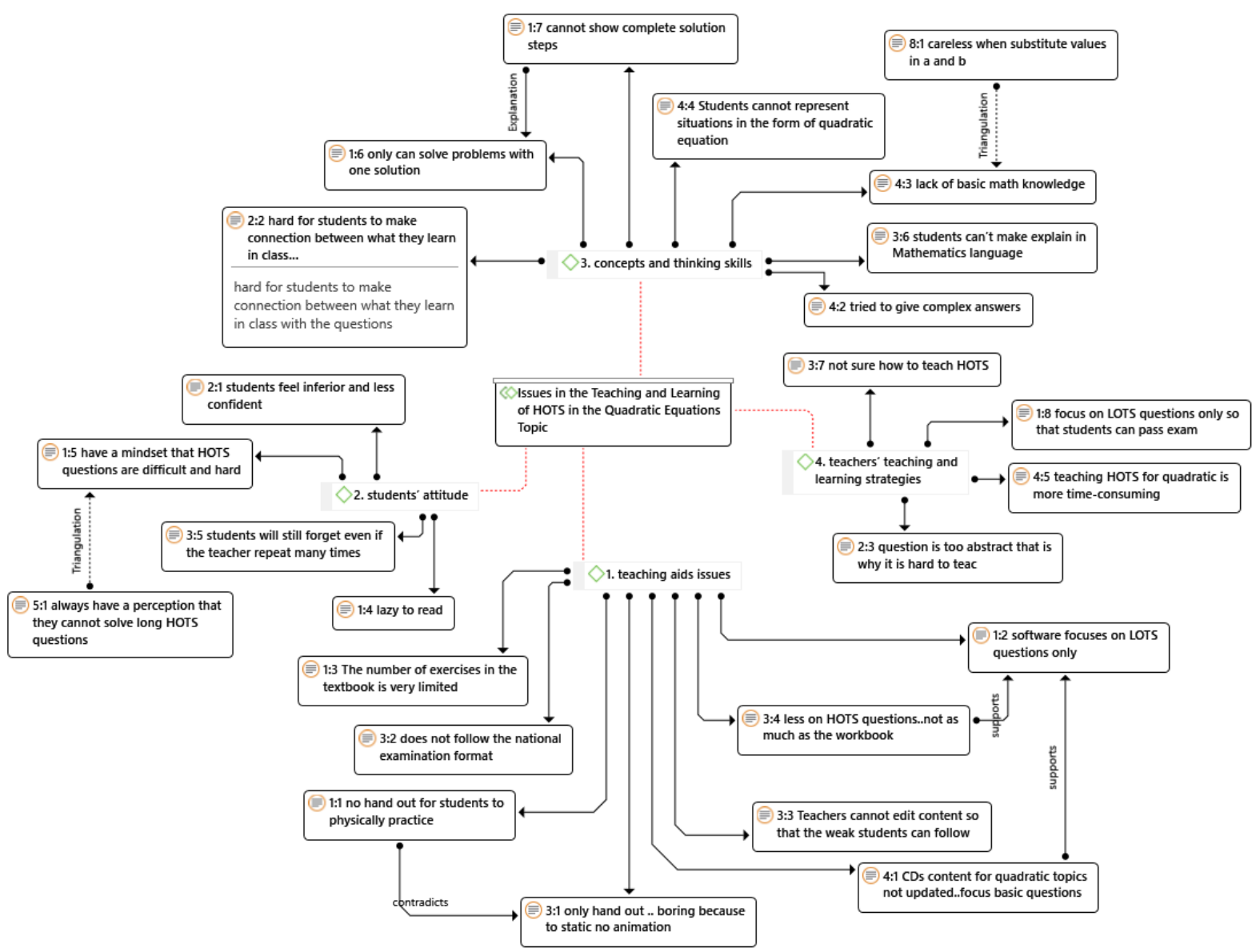

Figure 4. Issues in the Teaching and Learning of HOTS

The interviews with the teachers were able to identify a number of issues that exist in the context of teaching aids. One of the major obstacles is the lack of higher-order thinking skills-oriented teaching software for the topic of quadratic equations. Teacher 3 (G3) explained:

\section{G3: "...mostly the software in the market focus less on HOTS questions..not as much as the} workbook.".

(Int-G3-15/7/2020: 74-75)

G1 also agreed that the scarce availability of teaching aids software from local publishers imposes significant difficulty to implement the teaching and learning sessions of higher-order thinking skills for quadratic equations:

\section{G1: "...drilling HOTS questions in the form of software are limited to one or two only.......most software like Malaysian Certificate of Education (MCE) Score A+ software focuses on LOTS questions only."}

(Int-G1-15/7/2020: 90-91)

G3 stated that higher-order thinking skills questions that are prepared and available in the software are unclear and confuse the students because it does not conform with the national standard of assessment format. This includes higher-order thinking skills in quadratic equation questions in existing software that are irrelevant to everyday situations and are not open-ended to include activities like discussing, explaining, analysing, and justifying.

Furthermore, G3 acknowledged that constraints in the teaching and learning of higher-order learning skills for the topic of quadratic equations also arise when teachers, especially those in rural schools, 
could not modify the content of the higher-order thinking skills software to suit their teaching techniques and students' needs. In addition to teaching aids in the form of software, the lack of exercise worksheets is also seen as a constraint for students to master this topic. Such physical training is able to motivate students to be more self-confident and courageous in solving more challenging problems. This is further reinforced by the statement by G1:

G1: "...software is to show pictures in the questions but it is difficult..because students only see.. there is no hand out for students to physically practice doing the steps."

(Int-G1-15/7/2020: 86-89)

The study also found various interview excerpts shared by all four teachers pertaining to the code of students' attitude. It includes the students' initial impression that the learning of higher-order thinking skills for the topic of quadratic equations is difficult. This is because the higher-order thinking skills' problem solving is wordy and written in long sentences, as well as the influence from other factors. This was stated by $\mathrm{G} 1$ as follows:

G1: "Students always ignore HOTS questions in examinations or tests because they already have a mindset that HOTS questions are difficult and hard."

(Int-G1-15/7/2020: 83-85)

G1 further added:

G1: "when students see long questions, they feel lazy to read...some students said HOTS Mathematics questions are like Malay language essay questions because it has too many words..."

(Int-G1-15/7/2020: 81-83)

Meanwhile, Teacher G2 expressed:

G2: "many students feel inferior and less confident to give the correct solution when answering HOTS questions... that is why students can only answer correctly halfway."

(Int-G3-15/7/2020: 83-85)

The students' attitude of disbelieving in themselves can have negative implications on their verbal or written expression of ideas and information, which in return affects their understanding of the topic.

Issue on the mastery of concepts and thinking skills among students is another obstacle for them to master higher-order thinking skills in this topic. In general, students are unable to formulate a given situation into an accurate concept of quadratic equation. This was posited by G4 as follows:

G4: "students could not represent the equation based on the given situation...they are not sure what topic to relate when solving HOTS questions."

(Int-G4-22/7/2020: 80-81)

G4 further added that the factor indirectly poses an impact to the students' misconception in representing the problems mathematically:

G4: "there was once, it was an easy problem question which was finding the roots of a quadratic equation, but they tried to give complex answers by adding the value of pie or convert to other metric unit." 
G2 also supported this statement by saying that students are unable to make connections between the quadratic equations contents that they have learned in class with the real world. This was confirmed by the following statement:
G2: "real-life situation like formulating quadratic equations based on the measurement of a paddy field or aquarium...it is really hard for students to make connection between what they learn in class with the questions....actually they do use the quadratic equations concept in their everyday life without they realising it."

(Int-G2-15/7/2020: 76-79)

Aside from the difficulty to form conceptual connections, students also face problems in solving higherorder thinking skills problems that involve more than one method or may have more than one solution. To quote G1:

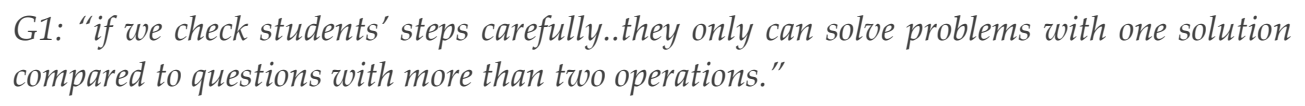

(Int-G1-15/7/2020: 97-99)

G1 also said that her personal analysis on the examination national papers indicates that students are only capable to show complete steps of work for low order thinking skills questions.

Meanwhile, results from the interview indicated that negligence and mistakes often occur when students attempt to solve problems related to quadratic equations. This is due to the lack of basic knowledge in the topic. As pointed out by G4:

G4: "students will make mistakes..mistakes happen because lack of basic math knowledge such as addition and subtraction operations that involve quadratic equations and negative number transfer."

(Int-G4-22/7/2020: 90-92)

The above statement is further supported by an example of the mistake in calculation steps, given during the interview triangulation with Teacher $4(\mathrm{G} 4)$ :

G4: "students often become careless when answering HOTS questions.. always careless when substitute values in a and b when forming the quadratic equation."

(IntT-G4-23/11/2020: 52-54)

Another issue identified under the code of problems in mastering the concepts and thinking skills is that students find it difficult to use language and mathematical symbols accurately when explaining an idea in the quadratic equations topic. This was propounded by G3 in the following example:

\footnotetext{
G3: ".for example, questions related to curved shape in the form of parabole based on quadratic equation... students can't make explain in Mathematics language whether the structure is safe or not based on calculation methods..even though the teacher has showed the correct steps many times."
}

$$
\text { (Int-G4-22/7/2020: 87-90) }
$$

Concepts in mathematics are abstract. Therefore, students are less skilled in explaining and translating mathematical problems using simple and accurate sentences as well as structured ideas.

From the teachers' perspective, the findings of this study also reported various constraints that exist within the teachers' teaching and learning strategies. One of the issues that caught the researcher by 
surprise was the teachers' confession on their lack of knowledge to implement higher-order thinking skills-based learning for the topic of quadratic equations. This was confirmed by the following statement by G3:

\section{G3: "Actually, I am not sure how to teach HOTS."}

(Int-G3-15/7/2020: 60)

It was also advocated by G2:

G2: "The HOTS concept in question is too abstract that is why it is hard to teach ...for example, the movement of a baseball that is modelled using quadratic equations ...erm..it is hard for me to demo"

(Int-G2-15/7/2020: 87-89)

Moreover, teachers are less likely to ask high level questions in testing students' thinking skills. This is due to their perception that producing students who barely pass the subject is merely sufficient. To quote G1:

\section{G1: "we also give insufficient HOTS exercises.. because want to focus on LOTS questions only so that students can pass exam..grade $E$ is enough for the school."}

(Int-G1-15/7/2020: 101-103)

Such approach that merely focuses on students passing the examination, or examination-oriented, subsequently prompts students to learn and memorise information solely for the purpose of passing the examination, thus encouraging the society to disregard the main purpose of assessments (Wilson \& Narasuman, 2020). Participant G4 was also in the opinion that the higher-order thinking skills questions posed were elaborated with long and complicated sentences. This poses a challenge for teachers to explain the step-by-step solution within the allotted teaching and learning hour.

Following a thorough analysis and discussion on the findings that were based on the three themes emerging from the structured interviews, the researcher found that teachers are yet to possess a proper and solid understanding on the implementation of higher-order thinking skills within the topic of quadratic equations. The misinterpretation of higher-order thinking skills in mathematics may lead to the implementation of incorrect instructions and actions, that can have serious consequences not only on the students but also to everyone involved (Ghazali, 2017). Hence, it is important to improve the teachers' understanding about the higher-order thinking skills elements integrated in the teaching of the quadratic equations topic.

Analysis of the transcript also demonstrated that higher-order thinking skills teaching style is mainly teacher-centred, which includes strategies like memorising the solution steps and focusing on merely passing the exam (exam-oriented). As stated by Nurlaily et al. (2021), mathematics education in schools nowadays is centred on learning that includes low order thinking skills which is oriented towards memorisation and simple understanding. Students are faced with increasingly complex problems so learning must be changed and led towards higher-order thinking skills-loaded learning. Such issue is critical as the findings by Chun and Abdullah (2019) have clearly suggested that teacher-centered learning approach is a practise that halts the instillation of higher-order thinking skills among students. Nevertheless, the findings in this study have stunned the researcher as the teachers admitted their preference towards the teacher-centred approach in teaching the quadratic equations topic.

This study also found that teachers commonly use demonstration as one of the approaches to teach quadratic equations. In general, teachers will demonstrate the procedures and steps to solve quadratic equations in front of their students and the students will follow these procedures without having critical 
evaluations. Although the purpose of this strategy is to strengthen the students' procedural knowledge, it may result in long term procedural errors particularly when students attempt to solve certain mathematical problems by implementing inappropriate and incorrect approach (Tendere \& Mutambara, 2020). In order to acquire accurate procedural knowledge, students should be equipped with prior understanding of the ideas to be addressed in order to employ appropriate steps in solving mathematical problems by following the rules, techniques, and procedures in various forms.

From the participants' perspective, it is important for the students to understand the topic as it is the fundamental mathematical skills for them to master before learning more advance topics. Students with high level of higher-order thinking skills are expected to succeed in their next study programme of mathematics education (Tanujaya et al., 2017). However, one prominent challenge faced by the teachers is to ensure that students can understand the requirements in each problem as well as able to find the roots of the quadratic equations, especially in applying the concept of higher-order thinking skills in everyday life. In summary, this study has reported various constraints faced by the teachers in their effort to implement higher-order thinking skill-based learning in quadratic equations topic. These constraints include students' acceptance, lack of teaching aids, thinking skills, and most importantly, the teachers' teaching strategies in the classroom. Improving teachers' understanding on how to overcome these challenges is fundamental especially during the teaching of higher-order thinking skills. The results of this study revealed that there is a lack of teachers' behaviour that nurtures higher-order thinking skills.

\section{CONCLUSION}

This study has demonstrated that Malaysian teachers possess limited understanding about each higherorder thinking skills level for the topic of quadratic equations. In fact, several participants in this study were only able to construct higher-order thinking skills problems by depending on workbooks. Among the constraint faced by teachers is the students inability to make connections between the quadratic equations contents that they have learned with real-world situations. The interview results also revealed that the existing teaching approaches mostly involve teacher-centred strategies that emphasize on the memorisation of facts and procedures as well as the steps to solve quadratic equation problems. Although recalling skills like determining the roots of quadratic equations using quadratic formula are important, teachers also play a role in stimulating students' thinking for them to be able to logically and rationally evaluate an idea. Blended learning, inquiry-based learning, cooperative learning, and projects, are among the alternative methods that can improve the teachers' teaching strategies in order to help students develop higher level of higher-order thinking skills. Teachers can also conduct projectbased learning such as charity events for the students to relate their sales results via quadratic equations. The teaching of higher-order thinking skills does not only revolve around asking 'difficult' questions alone, but generating students' knowledge even when it merely involves using their basic knowledge to explore learning naturally.

Finally, further studies are proposed by focusing on information and communications techonology (ICT) teaching styles such as the use of Desmos and GeoGebra Classic software applications in solving higher-order thinking skills problems for quadratic equations. The use of the qualitative approach with a limited sample size is an obvious limitation of this study as it prevents the generalization of the findings. Despite the important insights provided by this study, greater knowledge pertaining to the topic can be gained by recruiting more instructors via a survey questionnaire.

\section{POLICY IMPLEMENTATIONS}

Despite the implementation of various policies, programmes, and plans by the policymakers, teachers as implementers are still having limited understanding about higher-order thinking skills, which contradicts the initial expectation by the Ministry of Education. Accordingly, several measures can be taken to improve the teachers' teaching style in the implementation of higher-order thinking skills for the topic of quadratic equations. This includes making initial exposure by conducting workshops or the 
provision of guidance from individuals among the outstanding mathematics teachers. Apart from textbooks, mathematics teachers should also be given support such as a higher-order thinking skills module that can be used as a guide and reference in the teaching of quadratic equations. The Curriculum Development Division also needs to make necessary improvements to the higher-order thinking skills courseware and handbooks so that the teachers can apply them to their students.

Author contributions: All authors were involved in concept, design, collection of data, interpretation, writing, and critically revising the article. All authors approve final version of the article.

Funding: The authors received no financial support for the research and/or authorship of this article.

Declaration of interest: Authors declare no competing interest.

Data availability: Data generated or analysed during this study are available from the authors on request.

\section{REFERENCES}

Aling, M., \& Maat, S. M. (2021). Tahap penerapan dan kefahaman guru matematik terhadap kemahiran berfikir aras tinggi (KBAT) dalam PDP matematik di sekolah rendah [Level of application and understanding of mathematics teachers on higher order thinking skills (HLTS) in PDP mathematics in primary schools]. Jurnal Dunia Pendidikan, 3(1), 331-341. https://myjms.mohe.gov.my/index.php/jdpd/article/view/12587

Al-Kindi, N. S., \& AL-Mekhlafi, A. M. (2017). The practice and challenges of implementing critical thinking skills in Omani postbasic EFL classrooms. English Language Teaching, 10(12), 116-133. http://doi.org/10.5539/elt.v10n12p116

Aripin, N., Mustafa, H., \& Hussein, A. (2014). Hubungan kedinamikan dalaman dengan keberkesanan pasukan maya: Satu tinjauan di organisasi bertaraf Koridor Raya Multimedia (MSC) yang terpilih [The relationship of internal dynamics with virtual team effectiveness: A survey in selected Multimedia Super Corridor (MSC) -ranked organizations]. Jurnal Komunikasi: Malaysian Journal of Communication, 30, 191-218. https://doi.org/10.17576/JKMJC-2014-30SI-12

Bogdan, R., \& Biklen, S. K. (2007). Qualitative research for education: An introduction to theory and methods (5th ed.). Pearson A \& B.

Braun, V., \& Clarke, V. (2006). Using thematic analysis in psychology. Qualitative Research in Psychology, 3(2), 77-101. https://doi.org/10.1191/1478088706qp063oa

Cahyani, L., \& Rahaju, E. B. (2019). Students' reflective abstraction of middle school in reconstructing quadratic equation concept based on high mathematical ability. Journal of Physics: Conference Series, 1417(1), 012044. https://doi.org/10.1088/17426596/1417/1/012044

Chun, T. C., \& Abdullah, M. N. L. Y. B. (2019). The teaching of higher order thinking skills (HOTS) in Malaysian schools: Policy and practices. MOJEM: Malaysian Online Journal of Educational Management, 7(3), 1-18. https://doi.org/10.22452/mojem.vol7no3.1

Creswell, J. W. (2012). Educational research: Planning, conducting, and evaluating quantitative and qualitative (4th ed.). Pearson.

Curriculum Development Division. (2018). KSSM Dokumen Standard Kurikulum dan Pentaksiran Tingkatan 4 dan 5: Matematik [KSSM Form 4 and 5 Curriculum and Assessment Standard Document: Mathematics]. Kementerian Pendidikan Malaysia.

Didis, M. G., \& Erbas, A. K. (2015). Performance and difficulties of students in formulating and solving quadratic equations with one unknown. Educational Sciences: Theory \& Practice, 15(4), 1137-1150. https://doi.org/10.12738/estp.2015.4.2743

Friyatmi, M. (2020). Assessing students' higher order thinking skills using multidimensional item response theory. Problems of Education in the 21st Century, 78(2), 196-214. https://doi.org/10.33225/pec/20.78.196

Gani, M. F. R. (2018). Keberkesanan kemahiran berfikir aras tinggi pelajar dalam matematik melalui kaedah pembelajaran luar bilik darjah [The effectiveness of students 'high -level thinking skills in mathematics through extracurricular learning methods]. Journal of Advanced Research in Social and Behavioural Sciences, 10(1), 80-90. https://www.akademiabaru.com/doc/ARSBSV10_N1_P80_90.pdf

Ghazali, N. H. C. M. (2017). The implementation of School-Based Assessment System in Malaysia: A study of teacher perceptions. Geografia-Malaysian Journal of Society and Space, 12(9), 104-117. https:/ejournal.ukm.my/gmjss/article/view/17734/0

Güner, P. (2017). High school students' achievement of solving quadratic equations. Bartin University Journal of Faculty of Education, 6(2), 447-467. https://doi.org/10.14686/buefad.277494

Hadi, S., Retnawati, H., Munadi, S., Apino, E., \& Wulandari, N. F. (2018). The difficulties of high school students in solving higherorder thinking skills problems. Problems of Education in the 21st Century, 76(4), 520. https://doi.org/10.33225/pec/18.76.520

Hasan, A., \& Pardjono, P. (2019). The correlation of higher order thinking skills and work readiness of vocational high school students. Jurnal Pendidikan Teknologi dan Kejuruan, 25(1), 52-61. https://doi.org/10.21831/jptk.v25i1.19118

Hasan, B. (2019). The exploration of higher order thinking skills: students' difficulties and scaffolding in solving mathematical problems based on PISA. Journal of Physics: Conference Series, 1200, 012010. https://doi.org/10.1088/1742-6596/1200/1/012010

Hassan, M. N., Mustapha, R., Yusuff, N. A. N., \& Mansor, R. (2017). Pembangunan modul kemahiran berfikir aras tinggi di dalam mata pelajaran sains sekolah rendah: analisis keperluan guru [Development of high -level thinking skills modules in primary school science subjects: an analysis of teacher needs]. Sains Humanika, 9(1-5), 119-125. https://doi.org/10.11113/sh.v9n1-5.1185 
Irma-Ain, M. M. S., \& Zolkepeli, H. (2017). Kesediaan guru mengimplementasikan KBAT dalam pembelajaran dan pengajaran matematik sekolah rendah [Readiness of teachers to implement HOTS in primary school mathematics learning and teaching]. Jurnal Penyelidikan Pendidikan, 18, 147-159. https://anyflip.com/dixme/iaeh/basic/301-350

Johari, K., Ismail, Z., Osman, S., \& Othman, A. T. (2009). Pengaruh jenis latihan guru dan pengalaman mengajar terhadap efikasi guru sekolah menengah [The influence of teacher training types and teaching experience on the effectiveness of secondary school teachers]. Jurnal Pendidikan Malaysia (Malaysian Journal of Education), 34(2), 3-14. http://www.ukm.edu.my/jurfpend/journal/vol\%2034_2\%202009/pdf/Bab\%201.pdf

Jubri, N. Z. M., Zakaria, E., \& Matore, M. E. M. (2019). Penggunaan teknik jubin algebra dalam penguasaan kemahiran pendaraban ungkapan algebra bagi pelajar Tingkatan 2 [The use of algebraic tile techniques in the mastery of algebraic expression multiplication skills for Form 2 students]. Jurnal Dunia Pendidikan, 1(3), $74-88$. https://myjms.mohe.gov.my/index.php/jdpd/article/view/8314

Katz, V., \& Barton, B. (2007). Stages in the history of algebra with implications for teaching. Educational Studies in Mathematics, 66, 185-201. https://doi.org/10.1007/s10649-006-9023-7

Kotsopoulos, D. (2007). Unravelling student challenges with quadratics: A cognitive approach. Australian Mathematics Teacher, 63(2), 19-24. http://files.eric.ed.gov/fulltext/EJ769977.pdf

Li, L., Zeng, X., Yang, R., \& Wang, H. (2018). Mathematics teaching methods in high school. International Journal of Innovation and $\begin{array}{llll}\text { Research in } & \text { Educational } & \text { Sciences, } & \text { 354), }\end{array}$ http://www.ijires.org/administrator/components/com_jresearch/files/publications/IJIRES_1303_FINAL.pdf

Mahendran, K., Adenan, N. H., Abd Karim, N. S., Adawiyah, R., \& Junus, N. W. M. (2021). Analisis tahap Pengetahuan Pedagogi Kandungan (PCK) guru pelatih matematik [Analysis of the content pedagogical knowledge (PCK) stage for mathematics trainers]. Jurnal Pendidikan Bitara UPSI, 14, 72-81. https://doi.org/10.37134/bitara.vol14.sp.8.2021

Majid, M. A. A., Othman, M., Mohamad, S. F., Lim, S. A. H., \& Yusof, A. (2017). Piloting for interviews in qualitative research: Operationalization and lessons learnt. International Journal of Academic Research in Business and Social Sciences, 7(4), 10731080. https://doi.org/10.6007/IJARBSS/v7-i4/2916

Marzni, M. M., Rohizani, Y., Fadzilah A., Roselan B., \& Abdul R. J. (2018). Penggunaan teknologi mudah alih: Peralihan tumpuan untuk membudayakan kemahiran berfikir aras tinggi dalam sistem Pendidikan Bahasa Melayu [Use of mobile technology: A shift in focus to cultivate high -level thinking skills in the Malay Language Education system]. International Journal of Education and Training (InjET), 4(2), 1-9. http://psasir.upm.edu.my/id/eprint/54292/

McCarthy, J. (2020). Solving quadratic equations activity \& revisions. Ohio Journal of School Mathematics, 84(1), 71-89. https:/library.osu.edu/ojs/index.php/OJSM/article/view/6997

Misrom, N. B., Muhammad, A., Abdullah, A., Osman, S., Hamzah, M., \& Fauzan, A. (2020). Enhancing students' higher-order thinking skills (HOTS) through an inductive reasoning strategy using geogebra. International Journal of Emerging Technologies in Learning (iJET), 15(3), 156-179. https://doi.org/10.3991/ijet.v15i03.9839

Nasir, C. M. N \& Hamid, N. A. (2017). Eksplorasi penggunaan ketum dalam kalangan belia di Negeri Kedah [Exploration of ketum use among youth in Kedah]. Jurnal Pembangunan Sosial, 20, 1-14. http://doi.org/10.32890/jps.20.2017.11549

Norton, S. (2015). Teaching and learning fundamental mathematics: Quadratic equations. Producer Freddy Komp.

Nurlaily, V. A., Sholihah, H. I. A., Wulandari, R. A., \& Sa'diyah, A. (2021, March). The development of HOTS-dased mathematics teaching materials in elementary school. Journal of Physics: Conference Series, 1842(1), 012042. https://doi.org/10.1088/17426596/1842/1/012042

O'Connor, B. R., \& Norton, S. (2016). Investigating students' mathematical difficulties with quadratic equations. In B. White, M' Chinnappan, \& S. Trenholm (Eds.), Opening up mathematics education research, Proceedings of the 39th annual conference of the Mathematics Education Research Group of Australasia [MERGA] (pp. 552-559). MERGA.

Rashidi, M. N., Begum, R. A., Mokhtar, M., \& Pereira, J. J. (2014). The conduct of structured interviews as research implementation method. Journal of Advanced Research Design, 1(1), 28-34. http://www.myjurnal.my/public/articledownload.php?id=102628

Rosli, R. A., \& Rasdi, N. (2015). Analisis kesilapan pemfaktoran ungkapan kuadratik dalam kalangan pelajar Semester Satu di Politeknik Sultan Idris Shah [Analysis of quadratic expression factorization errors among Semester One students at Sultan Idris Shah Polytechnic]. In 1st National Conference on Business and Innovation 2015 (pp. 599-609). Politeknik Sultan Salahuddin Abdul Aziz Shah.

Sağlam, R., \& Alacacı, C. (2012). A comparative analysis of quadratics unit in Singaporean, Turkish and IMDP mathematics textbooks. Turkish Journal of Computer and Mathematics Education, 3(3), 131-147. https://dergipark.org.tr/tr/download/article-file/201331

Sari, I. F. D. P., \& Jailani, J. (2019). Error analysis for grade IX students in completing the materials of quadratic equation. Annals of Mathematical Modeling, 1(2), 64-80. https://doi.org/10.33292/amm.v1i2.38

Spencer, L. M., \& Spencer, P. S. M. (1993). Competence at Work models for superior performance. Wiley India Pvt.

Suanto, E., Zakaria, E., \& Maat, S. M. (2019). Impak pendekatan pembelajaran pengalaman terhadap kemahiran berfikir aras tinggi topik bongkah geometri tiga dimensi [Impact of experiential learning approach on higher order thinking skills topic of three dimensional geometric blocks]. Jurnal Pendidikan Malaysia (Malaysian Journal of Education), 44(1SI), 121-135. https://doi.org/10.17576/JPEN-2019-44.01SI-10 
Talib, O. (2019). Analisis data kualitatif dengan ATLAS.ti 8. UPM Publication.

Tall, D., de Lima, R. N., \& Healy, L. (2014). Evolving a three-world framework for solving algebraic equations in the light of what a student has met before. Journal of Mathematical Behavior, 34, 1-13. https://doi.org/10.1016/j.jmathb.2013.12.003

Tanujaya, B., Mumu, J., \& Margono, G. (2017). The relationship between higher order thinking skills and academic performance of student in mathematics instruction. International Education Studies, 10(11), 78-85. https://doi.org/10.5539/ies.v10n11p78

Teh, A. H. (2015). Kaedah Pemfaktoran Ajaib Ungkapan Kuadratik (P.A.U.K) [Magic Factorization Method of Quadratic $\begin{array}{llllll}\text { Expressions } & \text { (P.A.U.K)]. Jendidikan } & \text { Jurnal } & 122-131 .\end{array}$ http://ipkent.edu.my/document/pskent/pskent18/jurnal/142015/9.pdf

Tendere, J., \& Mutambara, L. H. N. (2020). An analysis of errors and misconceptions in the study of quadratic equations. European Journal of Mathematics and Science Education, 1(2), 81-90. https://doi.org/10.12973/ejmse.1.2.81

Waller, P. P., \& Flood, C. T. (2016). Mathematics as a universal language: transcending cultural lines. Journal for Multicultural Education, 10, 294-306. https://doi.org/10.1108/JME-01-2016-0004

Wilson, D. M., \& Narasuman, S. (2020). Investigating teachers' implementation and strategies on higher order thinking skills in school based assessment instruments. Asian Journal of University Education, 16(1), 70-84. https://doi.org/10.24191/ajue.v16i1.8991

Yeow P. C., Thavamani, R., Kamalah, R., Wong J. W., \& Santhanasamy V. D. (2019). Buku Teks Matematik Tingkatan Empat. Penerbit Pustaka Yakin.

Yin, R. K. (2014). Case study research design and methods (5th ed.). Sage.

Zakaria, E., Ibrahim, \& Maat, S. (2010). Analysis of students' error in learning of quadratic equations. International Education Studies, 3(3), 105-110. https://doi.org/10.5539/ies.v3n3p105

Zulkifli, F., Abidin, R. Z., Mansor, Z., Hamzah, M. H. M., \& Zulkipli, F. (2018). Penggunaan alat bantuan belajar bagi meningkatkan kemampuan berfikir pelajar. Jurnal Inovasi Malaysia, 1(2), 1-22. https:/ir.uitm.edu.my/id/eprint/23736/

Zulnaidi, H. (2013). Pembangunan dan keberkesanan modul pengajaran geogebra ke atas pengetahuan konseptual dan prosedural matematik fungsi dan had fungsi [Development and effectiveness of geogebra teaching modules on conceptual and procedural knowledge of functional mathematics and functional limits] [Doctoral thesis, Universiti Kebangsaan Malaysia]. 